\title{
Chinese Propolis Suppressed Pancreatic Cancer Panc-1 Cells Proliferation and Migration via Hippo-YAP Pathway
}

\author{
Lingchen Tao ${ }^{\dagger}, \mathrm{Xi} \mathrm{Chen}^{\dagger}$, Yufei Zheng, Yuqi Wu, Xiasen Jiang, Mengmeng You, Shanshan Li and Fuliang Hu * \\ College of Animal Sciences, Zhejiang University, Hangzhou 310058, China; 11817025@zju.edu.cn (L.T.); \\ 21717031@zju.edu.cn (X.C.); iriszheng92@gmail.com (Y.Z.); 11317024@zju.edu.cn (Y.W.); jxsen@zju.edu.cn (X.J.); \\ mmyou@zju.edu.cn (M.Y.); lishanshan@zju.edu.cn (S.L.) \\ * Correspondence: flhu@zju.edu.cn; Tel.: +86-571-889-829-52 \\ + These authors contributed equally to this work.
}

check for

updates

Citation: Tao, L.; Chen, X.; Zheng, Y.; Wu, Y.; Jiang, X.; You, M.; Li, S.; Hu, F. Chinese Propolis Suppressed

Pancreatic Cancer Panc-1 Cells

Proliferation and Migration via Hippo-YAP Pathway. Molecules 2021, 26, 2803. https://doi.org/10.3390/ molecules26092803

Academic Editors: Nada Orsolic and Maja Jazvinšćak Jembrek

Received: 3 March 2021

Accepted: 6 May 2021

Published: 10 May 2021

Publisher's Note: MDPI stays neutral with regard to jurisdictional claims in published maps and institutional affiliations.

Copyright: (c) 2021 by the authors. Licensee MDPI, Basel, Switzerland. This article is an open access article distributed under the terms and conditions of the Creative Commons Attribution (CC BY) license (https:/ / creativecommons.org/licenses/by/ $4.0 /)$.

\begin{abstract}
Pancreatic cancer is one of the most malignant cancers with high mortality. Therefore, it is of great urgency to develop new agents that could improve the prognosis of Pancreatic cancer patients. Chinese propolis (CP), a flavonoid-rich beehive product, has been reported to have an anticancer effect. In this study, we applied CP to the human Pancreatic cancer cell line Panc-1 to verify its impact on tumor development. CP induced apoptosis in Panc-1 cells from $12.5 \mu \mathrm{g} / \mathrm{mL}$ in a timeand dose-dependent manner with an $\mathrm{IC}_{50}$ value of approximately $50 \mu \mathrm{g} / \mathrm{mL}$. Apoptosis rate induced by CP was examined by Annexing FITC/PI assay. We found that $48 \mathrm{~h}$ treatment with $50 \mu \mathrm{g} / \mathrm{mL} \mathrm{CP}$ resulted in $34.25 \pm 3.81 \%$ apoptotic cells, as compared to $9.13 \pm 1.76 \%$ in the control group. We further discovered that the Panc- 1 cells tended to be arrested at G2/M phase after CP treatment, which is considered to contribute to the anti-proliferation effect of CP. Furthermore, our results demonstrated that CP suppressed Panc-1 cell migration by regulating epithelial-mesenchymal transition (EMT). Interestingly, the Hippo pathway was activated in Panc-1 cells after $\mathrm{CP}$ treatment, serving as a mechanism for the anti-pancreatic cancer effect of CP. These findings provide a possibility of beehive products as an alternative treatment for pancreatic cancer.
\end{abstract}

Keywords: Chinese propolis; pancreatic cancer; apoptosis; cell cycle arrest; migration; HippoYAP pathway

\section{Introduction}

Pancreatic cancer, a gastrointestinal malignant tumor, is one of the most aggressive cancers with an overall 5-year survival rate lower than 10\% [1]. GLOBOCAN 2018 report estimates that there will be 484,486 new cases of pancreatic cancer and 456,280 deaths caused by the disease in 2020 [2]. The occurrence and development of pancreatic cancer is a complex process, and smoking [3], alcohol [4], obesity [5], diabetes [6], chronic pancreatitis [7] are reported to contribute to pancreatic cancer, but its pathogenesis is still unclear. Although the detection and treatment of pancreatic cancer have advanced greatly in recent years, the incidence and mortality rate of pancreatic cancer has kept rising for the last decade [8]. The high mortality rate of pancreatic cancer is mainly ascribed to the difficulty in the early-stage diagnosis and the lack of efficient treatment. Lacking specific symptoms making it particularly difficult to diagnose pancreatic cancer at an early stage [9], resulting in a situation that most patients are diagnosed at an advanced stage with high metastases [10] and diffuse malignant peritoneal mesothelioma [11]. Currently, surgical resection is considered the only curative treatment for pancreatic cancer, but only $20 \%$ of patients are suitable for it [12]. Even those patients who have undergone resection have a high risk of recurrence [13]. Adjuvant methods like chemotherapy and radiotherapy are also widely used in pancreatic cancer treatment, but there is a large proportion of pancreatic cancer patients that develop drug resistance after treatment, leading to a poor prognosis [14]. Therefore, it is urgent to discover novel therapeutic methods to treat pancreatic cancer. 
The Hippo-YAP signaling pathway is responsible for adjusting the organ size, maintaining the dynamic balance between cell proliferation and apoptosis, as well as suppressing tumor development [15]. When the growth-inhibitory signal is transmitted to the cell membranes, the Hippo signaling pathway is activated, eventually leading to the phosphorylation of downstream effector YAP. YAP is an oncogene that can promote excessive cell proliferation by entering into nuclear and functioning as a transcription factor. Phosphorylated YAP (p-YAP) will bind to 14-3-3 protein in the cytoplasm and be degraded, thus regulating cell proliferation [16,17]. The inactivation of the Hippo pathway and overexpression of YAP have been observed in different malignancies, including liver cancer [18], colorectal cancer [19], and gastric cancer [20], and are associated with poor prognosis [21-23]. Growing Evidences showed that the Hippo pathway plays a critical role in the development of pancreatic cancer [13,22]. Increasing nuclear localization of YAP has been observed in pancreatic malignancy [21]. Deletion of YAP in the pancreas effectively suppressed the progression of pancreatic cancer in a Kras mutant mouse model [24]. Moreover, YAP overexpression can promote EMT by activating the AKT cascade, eventually enhancing chemoresistance in pancreatic cancer [22]. Taken together, these studies indicate that the Hippo-YAP pathway has the potential to be a new target for pancreatic cancer treatment. YAP, as an oncogene, can promote excessive cell proliferation and resist apoptosis. After inactivation of YAP phosphorylation, the expression of downstream target genes that promote cell proliferation decreases, thereby regulating the balance of cell proliferation and apoptosis and maintaining the normal volume of organs.

Propolis is a natural resinous substance that honey bees (Apis mellifera L.) collect from plant buds and is exuded in combination with bee's wax and salivary glands secretions [23]. Bees use propolis to build their hives and protect their colony from disease [24]. Propolis obtains various bioactive activities, such as antioxidant [25], anti-inflammatory [26], immunomodulatory [27], and antitumor effects [28]. The bioactive activities of propolis are dependent on its chemical composition, which is mainly affected by its botanical origin. Chinese propolis (CP) is generally of the poplar type whose main chemical components are flavonoids and phenolic compounds [29-31]. CP has a long history of being used in Chinese folk medicine. Increasing research has reported its anticancer effect on different cancer types, including breast cancer [32], liver cancer [28], and melanoma [33]. As a natural product, CP may provide a new method for cancer treatment. It was reported that propolis component caffeic acid phenethyl ester (CAPE) could inhibit the orthotopic growth and EMT of pancreatic cancer Panc-1 cells accompanied by the downregulation of vimentin and Twist 2 expression [34]. Other research has demonstrated a novel methodology in hyperthermia (HT) therapy called thermal cycle (TC)-HT. The synergistic anticancer effect of TC-HT and propolis was shown in pancreatic cancer cells [35]. In this study, we administered CP to Panc- 1 cells and found that CP could suppress pancreatic cancer cell viability by inducing apoptosis, promoting $\mathrm{G} 2 / \mathrm{M}$ cell cycle arrest, and inhibiting migration in Panc-1 cells by regulating EMT. Furthermore, we uncovered the mechanism underlying the anti-pancreatic cancer effect of $\mathrm{CP}$, which is by activating the Hippo-YAP pathway in Panc-1 cells.

\section{Results}

\subsection{Chemical Composition of CP Identified by High-Performance Liquid Chromatography (HPLC)}

The main components in ethanol extract of CP were identified by HPLC analysis (Figure 1). Result (Table 1) showed that chrysin (42.23 mg/g), galangin (38.94 mg/g), pinocembrin $(37.62 \mathrm{mg} / \mathrm{g}), 3-\mathrm{O}$-acetylpinobanksin $(35.89 \mathrm{mg} / \mathrm{g})$, pinobanksin $(30.21 \mathrm{mg} / \mathrm{g})$, and CAPE $(15.66 \mathrm{mg} / \mathrm{g}$ ) were the six most abundant components in ethanol extracts of CP. A previous study showed propolis component chrysin and galangin had a cytotoxic effect on pancreatic cells [36]. Furthermore, Duan et al. found that CAPE, which is the main constituent of Chinese propolis, suppressed the growth of pancreatic cancer in vitro [37]. Thus, we assumed that CP might exert an inhibitory effect on pancreatic cells. 


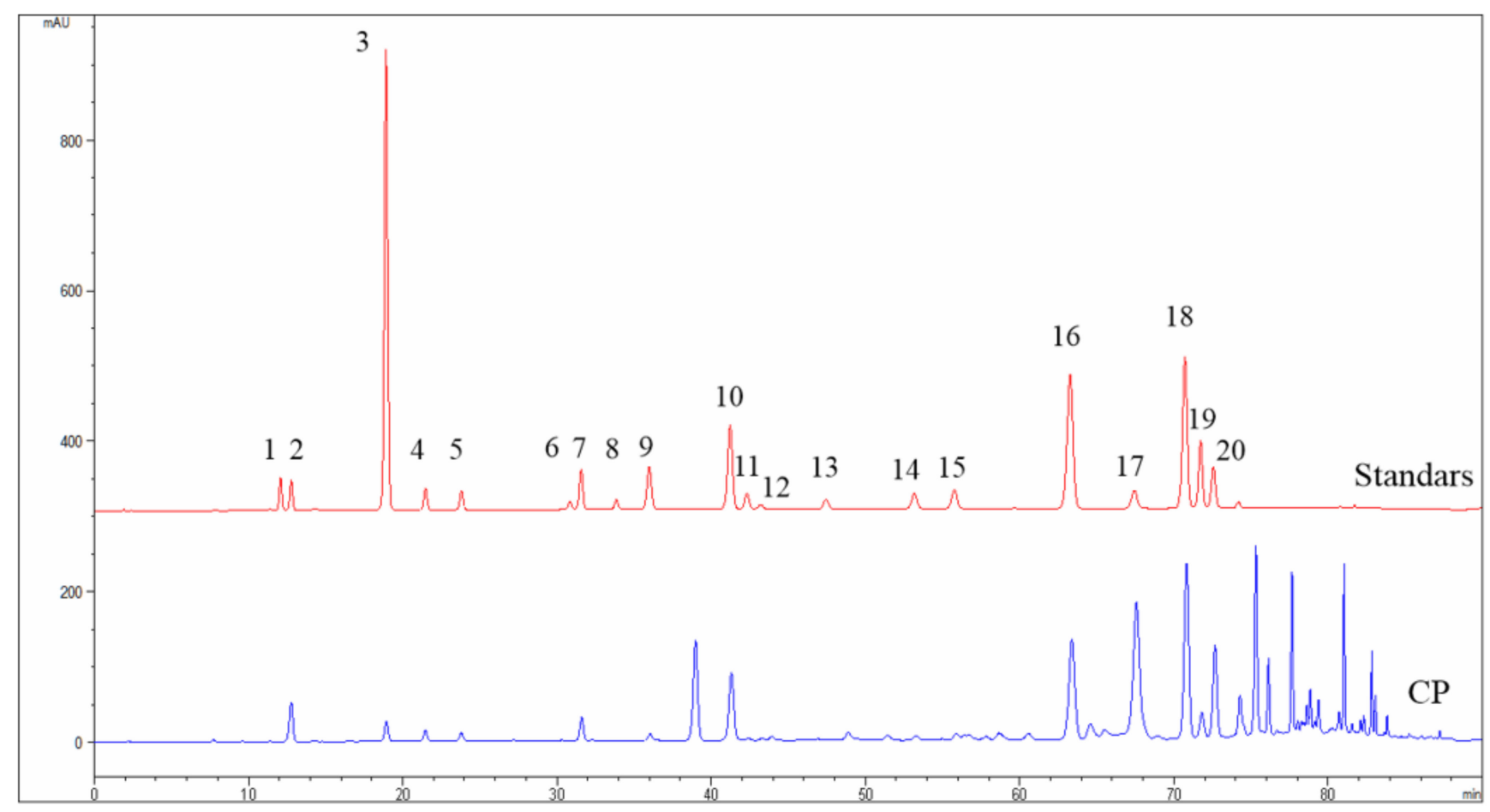

Figure 1. The HPLC chromatograms of standard solution and CP. 1: Vanillic; 2: Caffeic acid; 3: p-Coumaric acid; 4: Ferulic acid; 5: Isoferulic acid; 6: Rutin; 7: 3,4-Dimethoxycinnamic acid; 8: Myricetin; 9: Cinnamic acid; 10: Pinobanksin; 11: Naringenin; 12: Quercetin; 13: Luteolin; 14: Kaempferol; 15: Apigenin; 16: Pinocembrin; 17: 3-O-acetylpinobanksin; 18: Chrysin; 19: CAPE; 20: Galangin.

Table 1. The main components identified in CP by HPLC.

\begin{tabular}{cccc}
\hline Peak Number & Compounds & Retention Time (min) & Contents (mg/g) \\
\hline 1 & Vanillic & 12.274 & - \\
2 & Caffeic acid & 13.337 & 8.82 \\
3 & p-Coumaric acid & 19.421 & 7.36 \\
4 & Ferulic acid & 21.831 & 3.41 \\
5 & Isoferulic acid & 24.079 & 5.07 \\
6 & Rutin & 31.137 & - \\
7 & 3,4-Dimethoxycinnamic acid & 31.773 & 9.04 \\
8 & Myricetin & 33.743 & - \\
9 & Cinnamic acid & 32.597 & 0.87 \\
10 & Pinobanksin & 41.856 & 30.21 \\
11 & Naringenin & 42.603 & - \\
12 & Quercetin & 42.894 & 1.45 \\
13 & Luteolin & 47.682 & - \\
14 & Kaempferol & 53.397 & 2.73 \\
15 & Apigenin & 55.441 & 4.48 \\
16 & Pinocembrin & 63.857 & 37.62 \\
17 & 3-O-acetylpinobanksin & 67.032 & 35.89 \\
18 & Chrysin & 70.641 & 42.23 \\
19 & CAPE & 71.865 & 15.66 \\
20 & Galangin & 73.025 & 38.94 \\
\hline
\end{tabular}

\subsection{CP Exerted Cytotoxic Effect on Panc-1 Cells}

To investigate the cytotoxic effect of $\mathrm{CP}$, we evaluated the viability of Panc-1 cells after treated with varying concentrations of $\mathrm{CP}(6.25,12.5,25,50,100$, and $200 \mu \mathrm{g} / \mathrm{mL})$ using the cell counting-8 (cck-8) assay. We found that CP exerted a significant cytotoxic effect on human pancreatic Panc- 1 cells from $12.5 \mu \mathrm{g} / \mathrm{mL}$ in a time- and dose-dependent manner with an $\mathrm{IC}_{50}$ value of approximately $50 \mu \mathrm{g} / \mathrm{mL}$ for $48 \mathrm{~h}$ treatment (Figure 2A), 
while it did not show an inhibitory effect on HEK-293 cells (human embryonic kidney cell line) until the concentration reached $100 \mu \mathrm{g} / \mathrm{mL}$ (Figure 2B). According to these results, we treated Panc- 1 cells with CP at concentrations of $12.5,25$, and $50 \mu \mathrm{g} / \mathrm{mL}$ for $48 \mathrm{~h}$ in the following experiments.

A

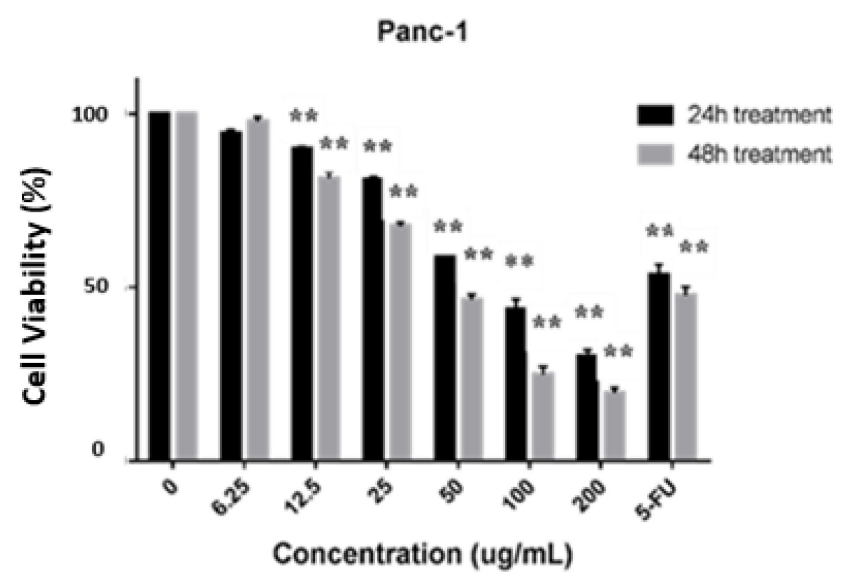

B

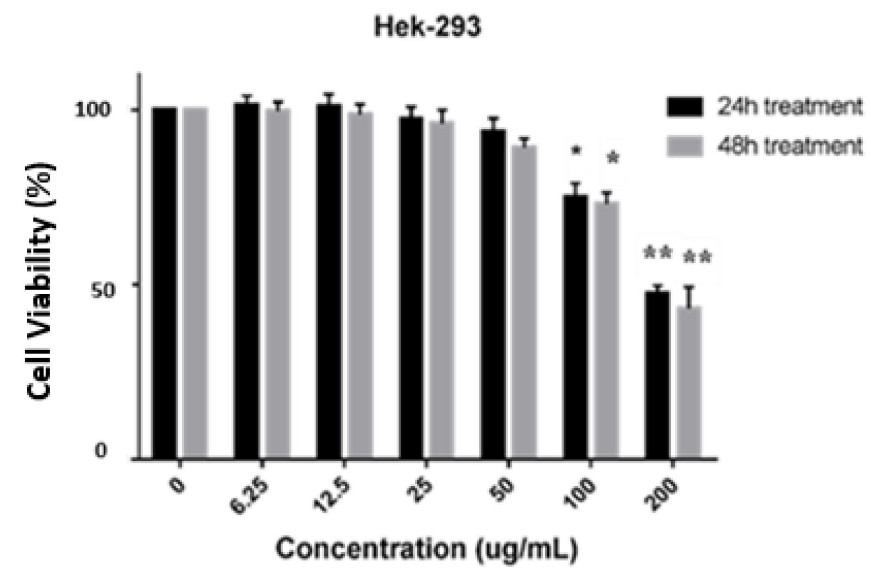

Figure 2. CP inhibited the viability of Panc-1 cells and had little effect on normal Hek-293 cells. (A) Panc-1 cells were treated with various concentrations of $\mathrm{CP}$ for 24 and $48 \mathrm{~h} .50 \mu \mathrm{M}$ Fluorouracil (5-FU) was used as a positive control. After treatment, CP exerted an anti-proliferation effect on Panc-1 cells. (B) CP showed no cytotoxic effect on normal HEK-293 cells until the concentration reaches $100 \mu \mathrm{g} / \mathrm{mL}$. Data are presented as mean $\pm \mathrm{SD} ;{ }^{*} p<0.05$ and ${ }^{* *} p<0.01$ versus control; $n=5$.

\subsection{CP Induced Apoptosis in Panc-1 Cells via Intrinsic Pathway}

We also examined the apoptosis rate induced by CP in Panc-1 cells using the Annexin V-FITC/PI assay. After treating cells with 12.5, 25, and $50 \mu \mathrm{g} / \mathrm{mL} \mathrm{CP}$ for $48 \mathrm{~h}$, the apoptotic cells significantly increased from $9.13 \% \pm 1.76 \%$ to $34.25 \% \pm 3.81 \%\left({ }^{*} p<0.01\right)$, as the concentration up to $50 \mu \mathrm{g} / \mathrm{mL}$ (Figure 3A).

Moreover, we verified the apoptotic effect of CP on Panc-1 cells by examining the apoptosis-related proteins. Results showed that pro caspase-3, pro caspase-8, pro caspase-9, cleaved caspase-3, cleaved caspase-8, cleaved caspase- 9 , and cleaved PARP were upregulated, while PARP1 full length was decreased after CP treatment for 48h (Figure 3B) in a dose-dependent manner. We further investigate the expression of mitochondrial proteins and found that the expression of Bcl-2 declined while the expression of Bax was increased, indicating mitochondrial dysfunction after CP treatment. Collectively, CP induced apoptosis in Panc-1 cells by activating the caspase cascade via the intrinsic pathway.

\subsection{CP Induced G2/M Cell Cycle Arrest in Panc-1 Cells by Interfering with Cell Cycle Checkpoints}

Studies have revealed that cell cycle arrest is an important mechanism during propolisinduced apoptosis [38-40]. To investigate the cell cycle distribution after CP treatment, we examined the cells with different concentrations of CP treatment for $48 \mathrm{~h}$ by using flow cytometry. Our data showed that Panc-1cells were arrested at the G2/M phase after CP treatment (Figure $4 \mathrm{~A}$ ). Compared to the $15.82 \% \pm 2.05 \% \mathrm{G} 2 / \mathrm{M}$ phase in the control group, cells in the G2/M phase rose to $28.42 \% \pm 1.42 \%$ in cells treated with a CP concentration of $50 \mu \mathrm{g} / \mathrm{mL}$.

Furthermore, we examined the expression of proteins related to cell cycle. Checkpoint kinase 1 phosphorylation (Chk1) is essential for DNA damage-induced cell cycle arrest, resulting in G2 phase blockage [41]. In our study, the expression level of p-chk1 was downregulated with a decline of p-cdc2 and cyclin B1 after 48 h CP treatment. Meanwhile, the expression of p21 was increased, which indicated that $\mathrm{CP}$ can interfere with cell cycle checkpoints to cause G2/M arrest (Figure 4B). 
A

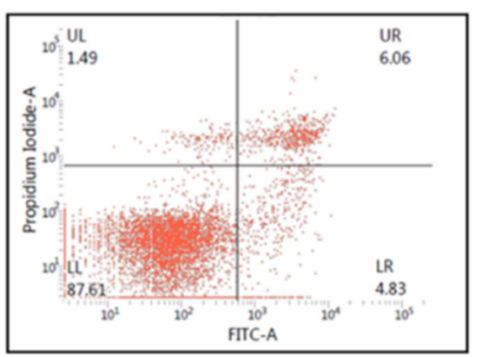

Control

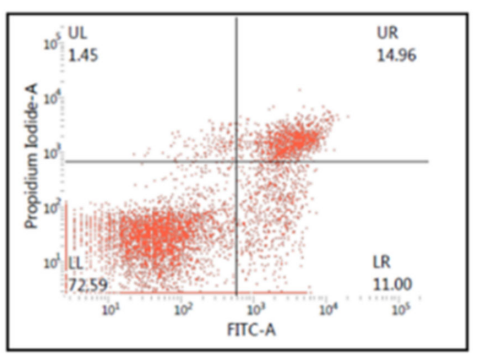

$25 \mu \mathrm{g} / \mathrm{mL}$

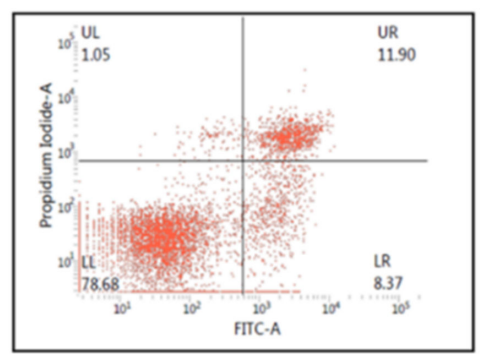

$12.5 \mu \mathrm{g} / \mathrm{mL}$

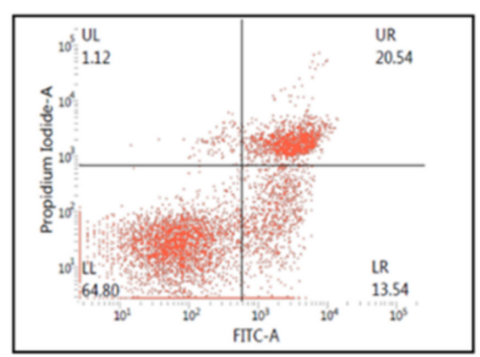

$50 \mu \mathrm{g} / \mathrm{mL}$

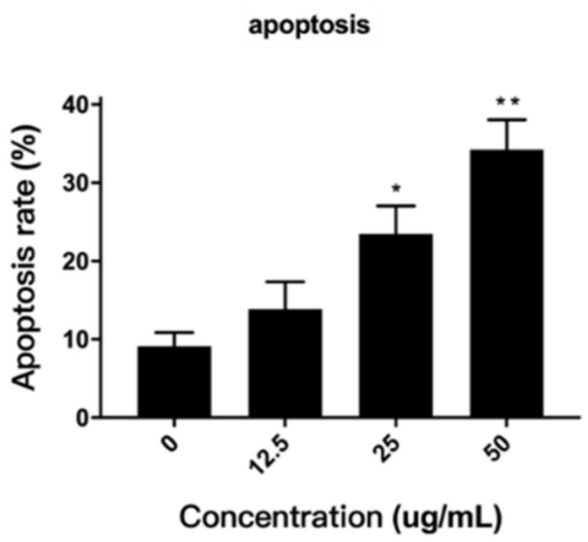

B

cleaved caspase-3 (17kDa)

cleaved caspase-8 $(18 \mathrm{kDa})$

cleaved caspase-9 (37kDa)

$\mathrm{Bcl}-2$ (26kDa)

$\mathrm{CP} \mu \mathrm{g} / \mathrm{mL}$

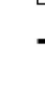
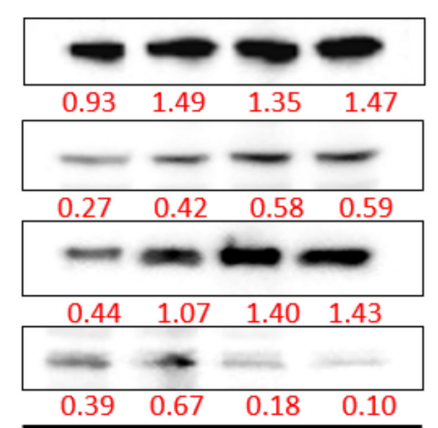

pro caspase-3 (32kDa)

pro caspase- $8(55 \mathrm{kDa})$

pro caspase-9 $(46 \mathrm{kDa})$

tubulin $(55 \mathrm{kDa})$

\section{$\mathrm{CP} \mu \mathrm{g} / \mathrm{mL}$}

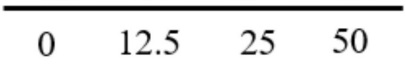

cleaved-PARP (89kDa)

PARP (116kDa)

tubulin $(55 \mathrm{kDa})$
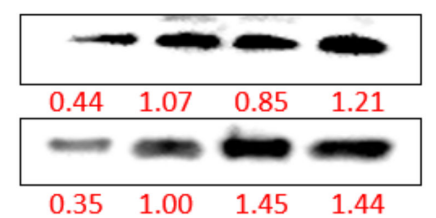

$\mathrm{CP} \mu \mathrm{g} / \mathrm{mL}$

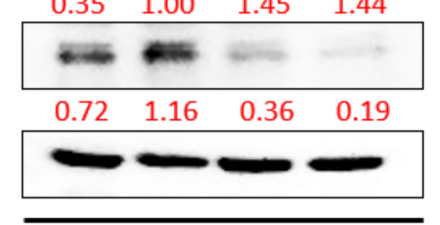

$\begin{array}{llll}0 & 12.5 & 25 & 50\end{array}$

Figure 3. CP induced apoptosis in Panc-1 cells by activating a caspase cascade. (A) CP significantly increased the apoptosis rate of Panc-1 cells in a dose-dependent manner. (B) Caspase cascade was activated after CP treatment; the expression of the caspase family of proteins was analyzed by Western blot. Data are presented as mean $\pm \mathrm{SD} ;{ }^{*} p<0.05$ and ${ }^{* *} p<0.01$ versus control; $n=3$.

\subsection{CP Suppressed Panc-1 Migration In Vitro by Regulating EMT}

Most advanced-stage patients of pancreatic cancer were characteristic as high metastasis, and those who have relapsed usually found liver metastasis [42]. We performed wound-healing experiment to investigate whether $\mathrm{CP}$ has an effect on the migration of 
Panc- 1 cells. As shown in Figure 5A, CP significantly inhibited cell migration in Panc-1 cells at a concentration of $6.5 \mu \mathrm{g} / \mathrm{mL}$, which is a non-fatal concentration.

Evidence has shown that the epithelial-mesenchymal transition (EMT) contributes to metastasis by enhancing tumor migration and progression [43]. Thus, we examined the expression of EMT-related proteins. The decline mesenchymal cell markers, including Snail, Vimentin, and N-cadherin were observed (Figure 5B). We also found that $\mathrm{CP}$ restored E-cadherin expression after $48 \mathrm{~h}$ treatment, indicating that $\mathrm{CP}$ inhibited migration of Panc-1 cells by reversing the EMT process.

A

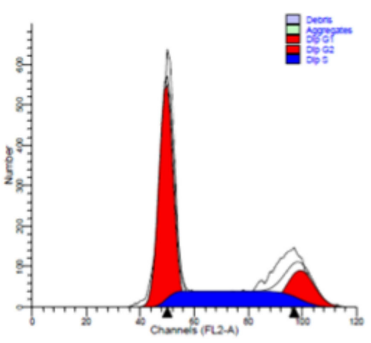

Control

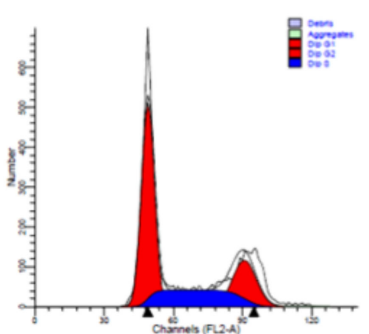

$25 \mu \mathrm{g} / \mathrm{mL}$

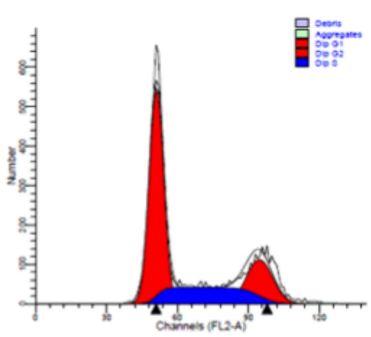

$12.5 \mu \mathrm{g} / \mathrm{mL}$

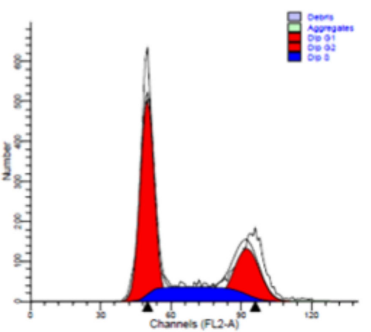

$50 \mu \mathrm{g} / \mathrm{mL}$

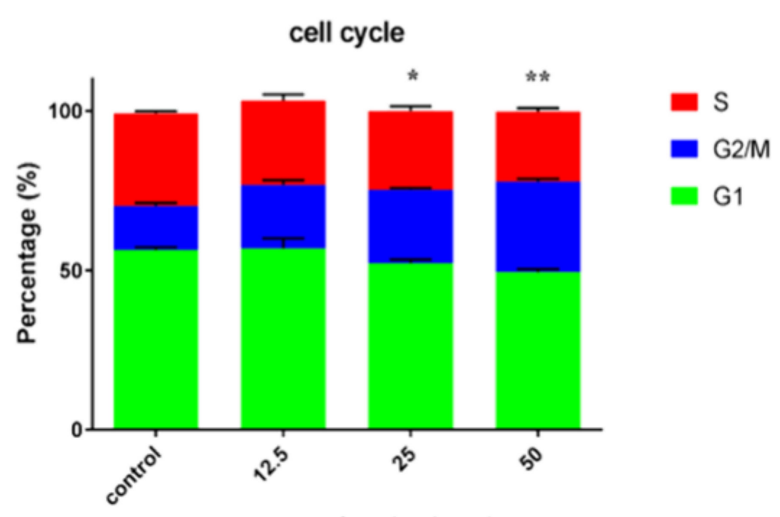

Concentration $(\mu \mathrm{g} / \mathrm{mL})$

B

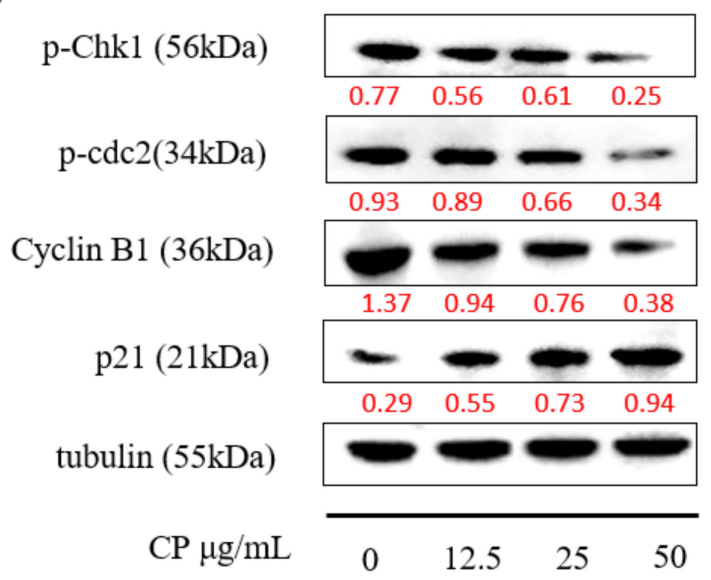

Figure 4. CP promoted G2/M phases cell cycle arrest in Panc-1 cells. (A) The cell cycle distribution after CP treatment at the concentration of $12.5,25$, and $50 \mu \mathrm{g} / \mathrm{mL}$ for $48 \mathrm{~h}$. (B) Cell cycle checkpoint protein expression was analyzed by Western blot. Data are presented as mean $\pm \mathrm{SD}^{*} p<0.05$ and ${ }^{* *} p<0.01$ versus control; $n=3$.

\subsection{CP Exerted Anti-Tumor Effect on Panc-1 Cells via Hippo-YAP Pathway}

Flavonoids, the most abundant component in propolis, were reported to inhibit the proliferation of cancer cells by activating the Hippo-YAP pathway [44,45], and Hippo-YAP is critical for pancreatic cancer development. Combining with our research, we inferred that the Hippo-YAP pathway might also play a role in the anticancer effect of CP. A previous study observed an increase in the nuclear location of YAP in pancreatic cancer [21]; thus, 
we examined YAP nuclear accumulation by immunofluorescence staining. The results (Figure 6A) showed nuclear-localized YAP was decreased after CP treatment for $48 \mathrm{~h}$.

Additionally, we examined the expression of main components in the Hippo pathway (Figure 6B). Up-regulation of the upstream proteins LAST1 and MST1 were observed, with the activation of downstream effector protein YAP, confirmed with the increased expression of phosphorylated YAP (p-YAP) (Figure 6B). This result suggested the HippoYAP pathway was activated after $\mathrm{CP}$ treatment.

A

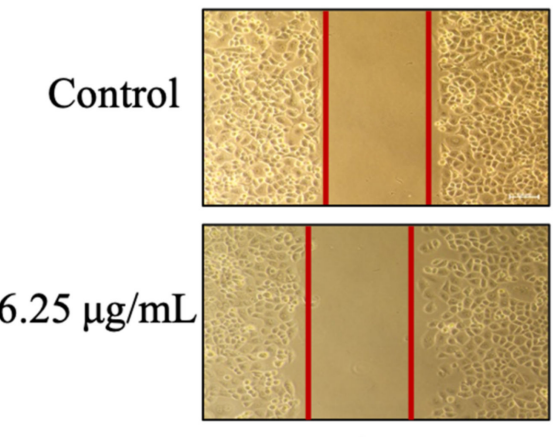

$\mathrm{Oh}$
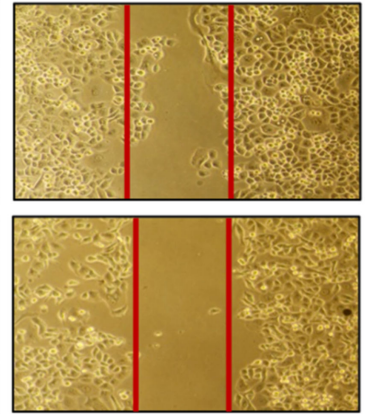

$24 \mathrm{~h}$
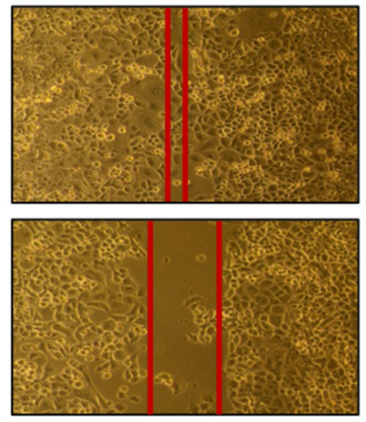

$48 \mathrm{~h}$

B

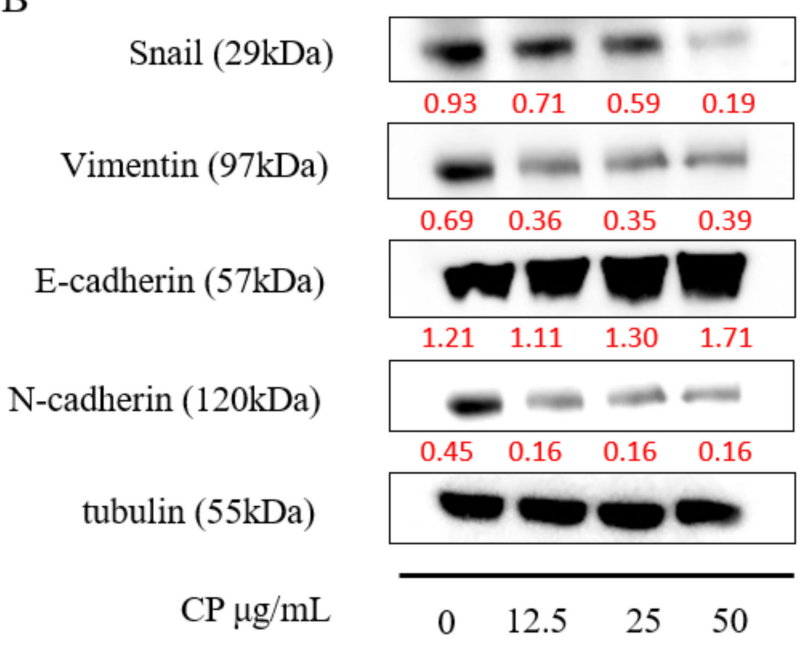

Figure 5. CP inhibited the migration of Panc-1 cells by inhibiting the EMT process. (A) CP suppressed migration of Panc-1 cells at a non-fatal concentration of $6.25 \mu \mathrm{g} / \mathrm{mL}$. (B) The expression of EMT-related proteins was analyzed by Western blot with different concentrations and treatment times. 
A

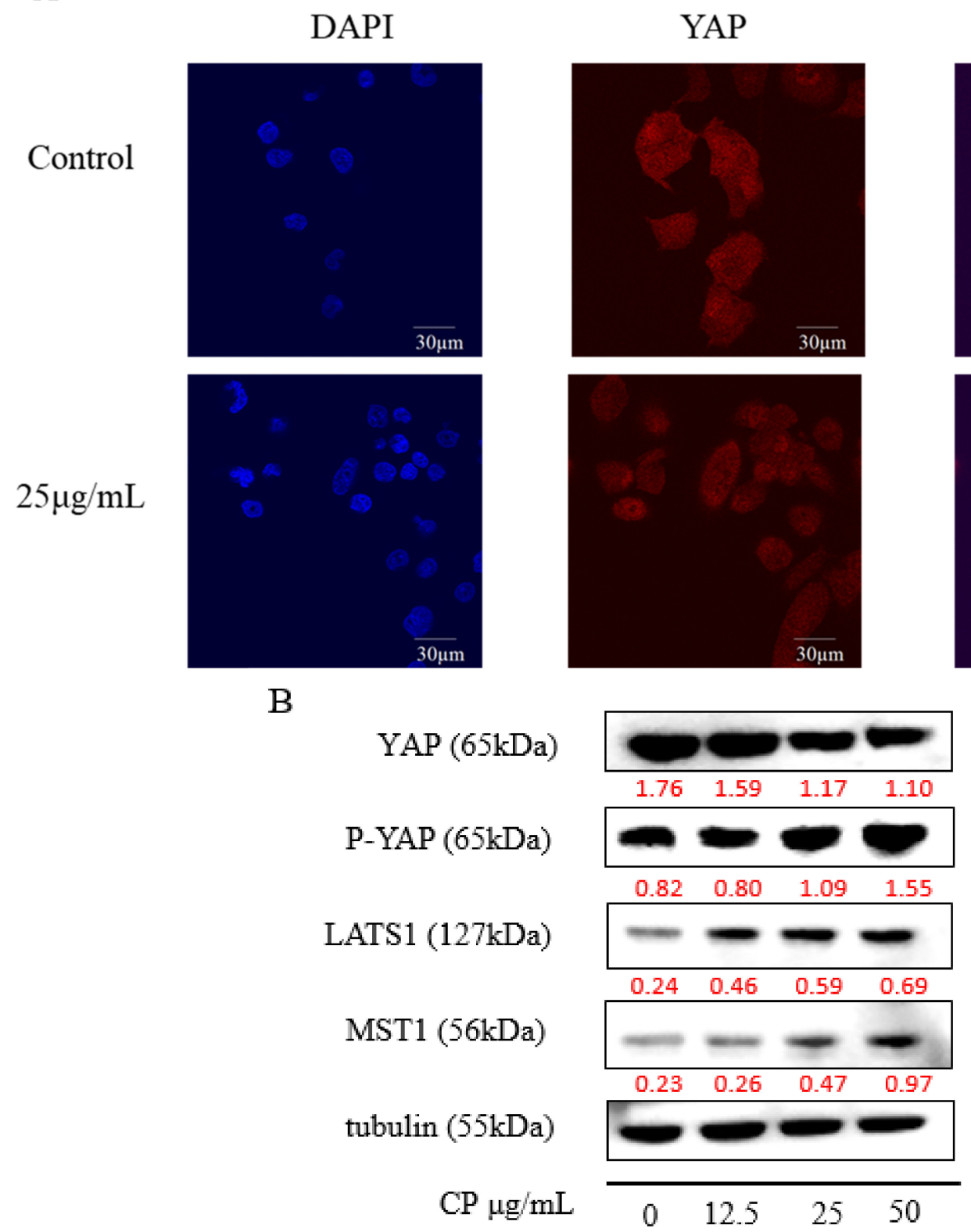

Figure 6. CP exerted an anti-tumor effect on Panc-1 cells by regulating the Hippo-YAP pathway. (A) Immunofluorescence image of YAP in Panc-1 cells treated with CP for $48 \mathrm{~h}$. (B) The expression of the main components in the Hippo-YAP pathway, including YAP, p-YAP, LATS1, and MST1, detected by Western blot.

\section{Discussion}

Despite advances in diagnostic tools and treatment methods for pancreatic cancer, the incidence of pancreatic cancer is still continually rising, which was estimated to have reached 484,486 in 2020 [2,8]. Growing research is paying attention to the anti-tumor effect of $\mathrm{CP}$, and previous studies have shown that $\mathrm{CP}$ can inhibit the growth of different cancers $[33,46]$. However, there are few studies addressing the effect of $\mathrm{CP}$ in pancreatic cancer. In this study, we firstly revealed the inhibitory effect of $\mathrm{CP}$ on pancreatic cancer cells in vitro and investigated the mechanism under it, which could not only bring new methods to treat pancreatic cancer but also lay the groundwork for further application of propolis.

Since the biological activities of propolis are determined by its components, we identified the chemical composition of the $\mathrm{CP}$ we used in this study. The results showed that 
chrysin, pinocembrin, 3-O-Acetylpinobanksin, galgangin, and CAPE were the main components (Figure 1), which was consistent with a previous study [47]. Mexico propolis and its components, including chrysin, pinocembrin, and 3-O-acetylpinobanksin, has been shown to have a cytotoxic effect on Panc-1 cells [48]. To evaluate whether Chinese propolis has an inhibitory effect on pancreatic cancer cell viability, we conducted a CCK-8 assay. In this study, CP showed a time- and dose-dependent inhibitory effect on Panc-1 cell viability (Figure 2). Consistent with the decreased cell viability, the cell apoptosis rate significantly rose as $\mathrm{CP}$ concentration increased (Figure $3 \mathrm{~A}$ ). To investigate the molecular mechanism behind this, we examined the expression of apoptosis-related proteins by western blot. Activation of caspase cascade was observed by increasing cleaved caspase initiator (caspase-8 and caspase-9) and executioner (caspase- 3 and PARP). Apoptosis is a complex biochemical mechanism, and the extrinsic (death receptor pathway) and intrinsic (mitochondrial pathway) are considered the two main apoptotic pathways [49]. The intrinsic pathway of apoptosis is dependent upon the BCL-2 (B-cell CLL/Lymphoma 2) family for the efficient release of pro-apoptotic factors. We examined the expression of proteins from the Bcl-2 family and observed an increase of pro-apoptotic protein Bax, while anti-apoptotic protein $\mathrm{Bcl}-2$ declined after $48 \mathrm{~h} \mathrm{CP}$ treatment. Our results demonstrated that intrinsic apoptosis was triggered in CP-treated Panc-1 cells (Figure 3B). Additionally, we found that Panc-1 cells were arrested in the G2/M phase after CP treatment (Figure 4A). G2/M phase was regulated by the complex formed by Cyclin B1 and cdc2 (also known as CDK1) [50]. In order to study the specific mechanism of $\mathrm{CP}$ influencing the cell cycle, we detected the expression of proteins related to cell cycle checkpoints by Western blot. After CP treatment, the expression of p-chk1 was down-regulated (Figure 4B), which led to the suppression of downstream factors $\mathrm{p}$-cdc2 and cyclin B1 [51]. The down-regulation of p-cdc2, along with the decline of Cyclin B1, contributed to DNA-damage-induced G2/M arrest [52]. Besides, $\mathrm{P} 21$, as a CDK inhibitor, can inhibit G2/M progression by directly interacting with the CyclinB-cdc2 complex [41,53], which was also decreased in the current study.

The high mortality rate of pancreatic cancer is partly due to its metastatic characteristics [42,54]. The metastatic rate of Panc- 1 cells was decreased significantly after CP treatment (Figure 5A), revealed by a wound healing test. EMT is regarded as a critical step of metastasis. Cells dissociate from the epithelial layer, deregulates cell-cell junctions, and enhances migratory capacity [55]. The lack of E-cadherin is considered a mark of EMT [56]. A previous study has shown that repression of E-cadherin could promote a metastatic phenotype in many cancer types including pancreatic cancer [57]. Along with the reduction of E-cadherin, an increase of mesenchymal marker proteins including N-cadherin, vimentin, and smooth muscle actin were also observed during the EMT process [58]. Snail is one of the EMT-inducing transcription factors, which can repress E-cadherin expression by interacting with chromatin remodeling factors [59-61]. Studies have reported that propolis and its components can regulate metastasis of cancer cells by inhibiting EMT [62-66]. Thus, we performed western blot to examine whether CP had an effect on the EMT process of Panc-1 cells. In this study, Snail and mesenchymal proteins such as N-cadherin, Vimentin were decreased, while E-cadherin was increased after CP treatment (Figure $5 \mathrm{~B}$ ), which indicated that $\mathrm{CP}$ inhibited pancreatic cancer metastasis by inhibiting the EMT.

The Hippo signaling pathway is associated with organ size control, cell differentiation, and metabolism regulation $[67,68]$. The Hippo pathway fulfilled its function by inactivating YAP actives. When the Hippo-YAP pathway is activated, the upstream kinases MST1/2 phosphorylate LATS1/2 by binding with the adapter protein SAV1/WW5. Then activated LAST1/2 phosphorylate and inactivate the effector protein YAP/TAZ by interacting with MOB1. The Phosphorylated YAP/TAZ then sequestered into the cytoplasm and eventually being degraded [69]. When the pathway was inactivated, it will lead to the overexpression and dephosphorylation of YAP/TAZ. Overexpressed YAP was translocated into nuclear to achieve its oncogenic function by interacting with transcriptional factors, including TEADs [70]. Pancreatic cancer was reported to express high-level YAP, 
which is confirmed to promote tumor development [71]. In our study, $\mathrm{CP}$ inhibited the nuclear localization of YAP (Figure 6A) and suppressed its expression in pancreatic cells. After CP treatment, expression of LATS1, MST1, and p-YAP was upregulated (Figure 6B), which suggested the activation of the Hippo pathway. These results indicated that the Hippo-YAP signaling pathway has a role in the anti-tumor effect of CP in Panc-1 cells. Furthermore, the Hippo pathway has been implied to interact with multiple pathways including mTOR [72], Wnt [73], Hedgehog [74], and Notch [75], to regulate the proliferation of cancer cells. Song et al. found YAP could inhibit apoptosis by binding with TEAD1 to regulate Bcl-2 activity [76]. Another study indicated that the Hippo pathway takes part in EMT by promoting the expression of FOXC2, Snail, and Twist [77]. Besides, YAP can promote EMT by binding with transcriptional factor FOS to upregulate the expression of Slug and Vimentin [78]. In our study, we also observed the down-regulation of Snail and Vimentin along with the decline of YAP after CP treatment. Additionally, LATS1 activation leads to cell cycle arrest at the G2/M phase by regulating Cyclin kinase/cdc2 activities [79]. Combined with our results, the Hippo pathway may have a critical role in regulating Panc-1 cells by integrating with several other pathways after $\mathrm{CP}$ treatment.

Our study was conducted in pancreatic cancer cells in vitro. In future studies, we should purify, characterize and synthesize the active components in $\mathrm{CP}$ as well as transfer in vitro cell-based experiments to in vivo test systems for further verification. Currently, our findings only provide limited and preliminary evidence. Further studies should be carried out to determine the main effective components in propolis that induce the anticancer effect.

\section{Materials and Methods}

\subsection{Chemicals and Reagents}

Vanillic, caffeic acid, rutin, ferulic acid, isoferulic acid, p-coumaric acid, cinnamic acid, 3,4-dimethoxycinnamic acid, caffeic acid phenethyl ester (CAPE), myricetin, apigenin, galangin, chrysin, pinocembrin, quercetin, kaempferol, luteolin, and naringenin were purchased from Sigma-Aldrich (St. Louis, MI, USA), pinobanksin and 3-O-acetylpinobanksin were purchased from Ningbo Haishu Apexocean Biochemicals Co., Ltd. (Ningbo, China). High glucose Dulbecco's Modified Eagle's Medium (DMEM) and fetal bovine serum (FBS) were purchased from Gibco (NY, USA). 5-Fluorouracil (5-FU) was purchased from Sigma (St. Louis, MI, USA). Propidium iodide (PI), 4'6-diamidino-2-phenylindole (DAPI), and dimethyl sulfoxide (DMSO) were purchased from Sangon Biotechnology. Co. Ltd. (Shanghai, China). Cck-8 kit and the Annexin V Fitc apoptosis detection kit were purchased from Dojindo (Kumamoto, Japan). Cell cycle and apoptosis analysis kits were purchased from Beyotime (Shanghai, China). Primary antibodies against pro-caspase-3, pro-caspase-8, pro-caspase-9, cleaved-caspase-3, cleaved-caspase-8, cleaved-caspase-9, PARP, cleavedPARP, p-Chk1, p-cdc2, cyclin B1, Yap, p-Yap, MST1, tublin, anti-rabbit secondary antibodies, and goat anti-rabbit Alexa Fluor 594 secondary antibody were purchased from Abcam (Cambridge, MA, USA). Primary antibodies against Snail, E-cadherin, N-cadherin Vimentin, and LATS1 were purchased from Cell Signaling Technology (Danvers, MA, USA).

\subsection{Preparation of $C P$}

Raw CP was collected from the colony of Apis mellifera L. in Shandong Province, of which the main plant source was poplar. Raw propolis was extracted with $95 \%(v / v)$ ethanol at $40^{\circ} \mathrm{C}$ for $4 \mathrm{~h}$ in an ultrasonic water base, then put in a $4{ }^{\circ} \mathrm{C}$ refrigerator overnight and filtered the mixture solution with a paper filter; the extraction was repeated three times. The solution is then evaporated in a rotary evaporator at reduced pressure at $40{ }^{\circ} \mathrm{C}$ until a constant weight is reached. The resulted solution was redissolved in ethanol (95\%) to make a $50 \mathrm{mg} / \mathrm{mL}$ stock solution which was stored under a dry condition at $-20{ }^{\circ} \mathrm{C}$ for further use. 


\subsection{Cell Culture}

Panc-1 cells were purchased from the Cell Bank of the Chinese Academy of Sciences (Shanghai, China). Hek293 cells were gifted by Zhejiang University of Traditional Chinese Medicine. Both Panc-1 cells and Hek293 cells were cultured in DMEM medium supplemented with $10 \% \mathrm{FBS}$ and $100 \mathrm{U} / \mathrm{mol}$ of penicillin at $37^{\circ} \mathrm{C}$ in a humidified $95-5 \%(v / v)$ air and $\mathrm{CO}_{2}$, respectively. Cells were grown to $80-90 \%$ confluence before drug administration.

\subsection{Identification of $C P$ by HPLC}

Major compounds in CP were determined by HPLC as described in a previous study [18]. The separation was conducted on a Sepax HP-C18 column $(150 \mathrm{~mm} \times 4.6 \mathrm{~mm}$, $5 \mu \mathrm{m}$; Sepax Technologies, Inc., Newark, DE, USA), the flow rate is $1.0 \mathrm{~mL} / \mathrm{min}$ at $30^{\circ} \mathrm{C}$, and the injection volume was $5 \mu \mathrm{L}$. The mobile phases used were $0.1 \%$ aqueous acetic acid $(v / v$; mobile phase $\mathrm{A})$ and methanol (mobile phase $\mathrm{B})$, and the linear gradient model were set as follows: $25 \%$ to $55 \%$ (B) at 0 to $30 \mathrm{~min}, 55 \%$ to $80 \%$ (B) at 30 to $60 \mathrm{~min}, 80 \%$ to $95 \%$ (B) at 60 to $70 \mathrm{~min}$, and $95 \%$ to $25 \%$ (B) at 70 to $90 \mathrm{~min}$. The UV detector was performed at $280 \mathrm{~nm}$.

\subsection{Cell Viability Assay}

The cell viability was assessed by using a CCK-8 assay following the manufacturer's instructions. Panc-1 cells and Hek293 cells were seeded at the density of $2 \times 10^{4} / \mathrm{mL}$ into 96-well plates for $24 \mathrm{~h}$, then treated with varying concentrations of $\mathrm{CP}(6.25,12.5,25,50$, 100 , and $200 \mu \mathrm{g} / \mathrm{mL}$ ). After $24 \mathrm{~h}$ and $48 \mathrm{~h}$ treatment, $10 \mu \mathrm{L}$ of CCK-8 solution was added to cells and were then incubated at $37^{\circ} \mathrm{C}$ for $2 \mathrm{~h}$. The optical density (OD) was measured by using a microplate reader (Bio-Rad Model550, CA, USA) at $450 \mathrm{~nm}$.

\subsection{Cell Apoptosis Assay}

The cell apoptosis was assessed by using Apoptosis Detection Kit following the manufacturer's instructions. After $48 \mathrm{~h}$ treatment of $\mathrm{CP}(12.5,25$, and $50 \mu \mathrm{g} / \mathrm{mL})$, Panc-1 cells were harvested and washed twice with phosphate-buffered saline, then centrifuged. Cells were seeded into 6-well plates and treated with Annexin V-FITC and PI binding solution, then analyzed by flow cytometry with CellQuest (NJ, USA).

\subsection{Cell Cycle Assay}

Panc- 1 cells were cultured in $60 \mathrm{~mm}$ culture dishes at a density of $4 \times 10^{5}$ at $37^{\circ} \mathrm{C}$ overnight; then, the cells were treated with $12.5,25$, and $50 \mu \mathrm{g} / \mathrm{mL}$ of CP for $48 \mathrm{~h}$. After treatment, cells were collected and treated following the protocol of the Cell Cycle and Apoptosis Analysis kit. The cell cycle distribution was analyzed by flow cytometry with CellQuest (NJ, USA).

\subsection{Wound Healing Assay}

Two-well culture inserts (ibidi GmbH, Planegg, Germany) were used for the wound healing assay in vitro following the manufacture's protocol. After $24 \mathrm{~h}$, the insert was removed, forming a $500 \mathrm{~mm}$ width cell-free gap. Then the cells were treated with $6.25 \mu \mathrm{g} / \mathrm{mL}$ $\mathrm{CP}$, which is a non-fatal concentration. The migration rate was assessed by the healing areas, which were documented every $24 \mathrm{~h}$ with a microscope.

\subsection{Immunofluorescence Staining}

Panc- 1 cells were seeded in $20 \mathrm{~mm}$ glass-bottom cell culture dishes (NEST, Wuxi, China) to appropriate density, then fixed in $4 \%$ paraformaldehyde for $10 \mathrm{~min}$ and permeabilized with $0.1 \%$ Triton X-100 for 10 min. After blocking with 3\% BSA for 30 min, cells were incubated with the primary antibodies: monoclonal anti-YAP antibody diluted in $1 \%$ BSA in $4{ }^{\circ} \mathrm{C}$ overnight. Then cells were washed with PBS and incubated with Alex Flour 594-conjugated goat anti-rabbit IgG (1:250 dilution) for $1 \mathrm{~h}$ in the dark. The cells were 
then washed and stained with DAPI solution for $5 \mathrm{~min}$. The immunofluorescence result was obtained with a confocal laser microscope (Leica TCS SP5, Wetzlar, Germany).

\subsection{Western Blot}

Panc-1 cells were seeded into 6-well plates at a density of $1 \times 10^{6}$ cells/well with varying concentrations of CP. After $48 \mathrm{~h}$ treatment, cells were washed twice with pre-cold PBS twice on ice. Proteins were lysed with RIPA (Roche, Basel, Switzerland). Collecting and vortexed the cell lysate at 12,000 rpm for $10 \mathrm{~min}$, then put on ice for $10 \mathrm{~min}$ to remove the cell debris. Mixed the cellular protein with sample loading buffer (Fudebio, Hangzhou, China), then boiled the mixture at $95{ }^{\circ} \mathrm{C}$ for $10 \mathrm{~min}$. The BCA protein assay kit (Fudebio, Hangzhou, China) was used to measure the protein concentration, and $12 \%$ SDS-PAGE (Fudebio, Hangzhou, China) was used to separate the protein, which was then transferred to PVDF membranes (Millipore, Billerica, MA, USA). Blocked PVDF membranes with $5 \%$ skim milk (BD, NY, USA) dissolved in TBST solution for $1 \mathrm{~h}$ at room temperature, which were then incubated the immunoblots with specific primary antibodies overnight at $4{ }^{\circ} \mathrm{C}$. After primary antibody binding, incubating the blots with AP-conjugated anti-rabbit secondary antibodies for $1 \mathrm{~h}$ at room temperature. Beta-tublin was used as the internal control, and the immunoblots were developed with the ECL method.

\subsection{Statistical Analysis}

At least three experiments were conducted in each assay. All data are expressed as the mean \pm SD. The Student's $t$-test was used to determine statistical differences. $p<0.05$ was considered statistically significant difference $\left({ }^{*} p<0.05 ;{ }^{* *} p<0.01\right)$. Statistical analyses were performed using GraphPad Prism 6.0 (GraphPad Software Inc., CA, USA).

\section{Conclusions}

In conclusion, our study discovered an anti-tumor effect of $\mathrm{CP}$ on pancreatic cancer cells in vitro. In this study, CP induced apoptosis and promoted cell cycle arrest in Panc1 cells, which were considered to be the main mechanisms for CP to inhibit pancreatic cancer viability. Moreover, in vitro migration assays showed that CP suppressed Panc-1 migration by inhibiting the EMT process. Furthermore, we found that the Hippo-YAP signaling pathway was activated, which could be the mechanism of the anticancer effect of $\mathrm{CP}$. Our results could shed light on the potential pharmacological use of CP for pancreatic cancer treatment.

Author Contributions: Conceptualization, X.C. and Y.Z.; methodology, X.C., L.T., Y.Z., Y.W., X.J., and M.Y.; software, X.C.; validation, L.T., X.C., and Y.Z.; formal analysis, L.T. and X.C.; investigation, X.C., L.T., and X.J.; resources, S.L., Y.Z. and X.J.; data curation, X.C.; writing-original draft preparation, X.C. and L.T.; writing-review and editing, L.T., X.C., Y.Z., and Y.W.; visualization, L.T. and X.C.; supervision, F.H.; project administration, F.H.; funding acquisition, F.H. All authors have read and agreed to the published version of the manuscript.

Funding: The work was supported by an earmarked fund for Modern Agro-industry Technology Research System from the Ministry of Agriculture of China (CARS-44).

Institutional Review Board Statement: Not applicable.

Informed Consent Statement: Not applicable.

Data Availability Statement: The data presented in this study are available within the article.

Conflicts of Interest: The authors declare no conflict of interest.

Sample Availability: Samples of the compounds Chinese propolis are available from the authors.

\section{References}

1. Siegel, R.L.; Miller, K.D.; Jemal, A. Cancer statistics, 2020. CA Cancer J. Clin. 2020, 70, 7-30. [CrossRef] [PubMed]

2. Ferlay, J. GLOBOCAN 2008 v1.2, Cancer Incidence and Mortality World-Wide: IARC Cancer Base No. 10. Available online: https:/ / ci.nii.ac.jp/naid/20000625106/ (accessed on 2 June 2020). 
3. Bosetti, C.; Lucenteforte, E.; Silverman, D.T.; Petersen, G.; Bracci, P.M.; Ji, B.T.; Negri, E.; Li, D.; Risch, H.A.; Olson, S.H.; et al. Cigarette smoking and pancreatic cancer: An analysis from the International Pancreatic Cancer Case-Control Consortium (Panc4). Ann. Oncol. 2012, 23, 1880-1888. [CrossRef] [PubMed]

4. Wang, Y.-T.; Gou, Y.-W.; Jin, W.-W.; Xiao, M.; Fang, H.-Y. Association between alcohol intake and the risk of pancreatic cancer: A dose-response meta-analysis of cohort studies. BMC Cancer 2016, 16, 212. [CrossRef]

5. Davoodi, S.H.; Malek-Shahabi, T.; Malekshahi-Moghadam, A.; Shahbazi, R.; Esmaeili, S. Obesity as an Important Risk Factor for Certain Types of Cancer. Iran. J. Cancer Prev. 2013, 6, 186-194. [PubMed]

6. Stevens, R.J.; Roddam, A.W.; Beral, V. Pancreatic cancer in type 1 and young-onset diabetes: Systematic review and meta-analysis. Br. J. Cancer 2007, 96, 507-509. [CrossRef] [PubMed]

7. Raimondi, S.; Lowenfels, A.B.; Morselli-Labate, A.M.; Maisonneuve, P.; Pezzilli, R. Pancreatic cancer in chronic pancreatitis; aetiology, incidence, and early detection. Best Pract. Res. Clin. Gastroenterol. 2010, 24, 349-358. [CrossRef] [PubMed]

8. Bray, F.; Ferlay, J.; Soerjomataram, I.; Siegel, R.L.; Torre, L.A.; Jemal, A. Global cancer statistics 2018: GLOBOCAN estimates of incidence and mortality worldwide for 36 cancers in 185 countries. CA Cancer J. Clin. 2018, 68, 394-424. [CrossRef] [PubMed]

9. Spechler, S.J.; Sharma, P.; Souza, R.F.; Inadomi, J.M.; Shaheen, N.J. American gastroenterological association medical position statement: Epidemiology, diagnosis, and treatment of pancreatic ductal adenocarcinoma. Gastroenterology 1999, 117, 1463-1484. [CrossRef]

10. Humpton, T.J.; Alagesan, B.; DeNicola, G.M.; Lu, D.; Yordanov, G.N.; Leonhardt, C.S.; Yao, M.A.; Alagesan, P.; Zaatari, M.N.; Park, Y.; et al. Oncogenic KRAS Induces NIX-Mediated Mitophagy to Promote Pancreatic Cancer. Cancer Discov. 2019, 9, 1268-1287. [CrossRef]

11. Spanò, V.; Pennati, M.; Parrino, B.; Carbone, A.; Montalbano, A.; Cilibrasi, V.; Zuco, V.; Lopergolo, A.; Cominetti, D.; Diana, P.; et al. Preclinical Activity of New [1,2]Oxazolo[5,4-e]isoindole Derivatives in Diffuse Malignant Peritoneal Mesothelioma. J. Med. Chem. 2016, 59, 7223-7238. [CrossRef]

12. Ryan, D.P.; Hong, T.S.; Bardeesy, N. Pancreatic Adenocarcinoma. N. Engl. J. Med. 2014, 371, 1039-1049. [CrossRef]

13. Kamisawa, T.; Wood, L.D.; Itoi, T.; Takaori, K. Pancreatic cancer. Lancet 2016, 388, 73-85. [CrossRef]

14. Lockhart, A.C.; Rothenberg, M.L.; Berlin, J.D. Treatment for Pancreatic Cancer: Current Therapy and Continued Progress. Gastroenterology 2005, 128, 1642-1654. [CrossRef]

15. Yu, F.-X.; Zhao, B.; Guan, K.L. Hippo Pathway in Organ Size Control, Tissue Homeostasis, and Cancer. Cell 2015, 163, 811-828. [CrossRef]

16. Zhao, B.; Tumaneng, K.; Guan, K.-L. The Hippo pathway in organ size control, tissue regeneration and stem cell self-renewal. Nat. Cell Biol. 2011, 13, 877-883. [CrossRef]

17. Pan, D. Hippo signaling in organ size control. Genes Dev. 2007, 21, 886-897. [CrossRef]

18. Sohn, B.H.; Shim, J.-J.; Kim, S.-C.; Jang, K.Y.; Kim, S.M.; Kim, J.H.; Hwang, J.E.; Jang, H.-J.; Lee, H.-S.; Jeong, W.; et al. Inactivation of Hippo Pathway Is Significantly Associated with Poor Prognosis in Hepatocellular Carcinoma. Clin. Cancer Res. 2016, 22, 1256-1264. [CrossRef]

19. Lee, K.-W.; Lee, S.S.; Kim, S.-B.; Sohn, B.H.; Lee, H.-S.; Jang, H.-J.; Park, Y.-Y.; Kopetz, S.; Kim, S.S.; Oh, S.C.; et al. Significant Association of Oncogene YAP1 with Poor Prognosis and Cetuximab Resistance in Colorectal Cancer Patients. Clin. Cancer Res. 2015, 21, 357-364. [CrossRef]

20. Kang, W.; Tong, J.H.M.; Chan, A.W.H.; Lee, T.-L.; Lung, R.W.M.; Leung, P.P.S.; So, K.K.Y.; Wu, K.; Fan, D.; Yu, J.; et al. YesAssociated Protein 1 Exhibits Oncogenic Property in Gastric Cancer and Its Nuclear Accumulation Associates with Poor Prognosis. Clin. Cancer Res. 2011, 17, 2130-2139. [CrossRef]

21. Jiang, Z.; Zhou, C.; Cheng, L.; Yan, B.; Chen, K.; Chen, X.; Zong, L.; Lei, J.; Duan, W.; Xu, Q.; et al. Inhibiting YAP expression suppresses pancreatic cancer progression by disrupting tumor-stromal interactions. J. Exp. Clin. Cancer Res. 2018, 37, 69. [CrossRef]

22. Yuan, Y.; Li, D.; Li, H.; Wang, L.; Tian, G.; Dong, Y. YAP overexpression promotes the epithelial-mesenchymal transition and chemoresistance in pancreatic cancer cells. Mol. Med. Rep. 2015, 13, 237-242. [CrossRef] [PubMed]

23. Sforcin, J.M. Biological Properties and Therapeutic Applications of Propolis. Phytother. Res. 2016, 30, 894-905. [CrossRef] [PubMed]

24. Salatino, A.; Teixeira, É.W.; Negri, G.; Message, D. Origin and Chemical Variation of Brazilian Propolis. Evid.-Based Complement. Altern. Med. 2005, 2, 33-38. [CrossRef] [PubMed]

25. Boufadi, Y.M.; Van Antwerpen, P.; Alard, I.C.; Nève, J.; Djennas, N.; Riazi, A.; Soubhye, J. Antioxidant effects and bioavailability evaluation of propolis extract and its content of pure polyphenols. J. Food Biochem. 2017, 42, e12434. [CrossRef]

26. Wang, K.; Ping, S.; Huang, S.; Hu, L.; Xuan, H.; Zhang, C.; Hu, F. Molecular Mechanisms Underlying theIn VitroAnti-Inflammatory Effects of a Flavonoid-Rich Ethanol Extract from Chinese Propolis (Poplar Type). Evid.-BasedComplement. Altern. Med. 2013, 2013, 127672. [CrossRef] [PubMed]

27. Gao, W.; Wu, J.; Wei, J.; Pu, L.; Guo, C.; Yang, J.; Yang, M.; Luo, H. Brazilian green propolis improves immune function in aged mice. J. Clin. Biochem. Nutr. 2014, 55, 7-10. [CrossRef]

28. Frozza, C.O.D.S.; Santos, D.A.; Rufatto, L.C.; Minetto, L.; Scariot, F.J.; Echeverrigaray, S.; Pich, C.T.; Moura, S.; Padilha, F.F.; Borsuk, S.; et al. Antitumor activity of Brazilian red propolis fractions against Hep-2 cancer cell line. Biomed. Pharmacother. 2017, 91, 951-963. [CrossRef] 
29. Toreti, V.C.; Sato, H.H.; Pastore, G.M.; Park, Y.K. Recent Progress of Propolis for Its Biological and Chemical Compositions and Its Botanical Origin. Evid.-BasedComplement. Altern. Med. 2013, 2013, 1-13. [CrossRef]

30. Huang, S.; Zhang, C.-P.; Wang, K.; Li, G.Q.; Hu, F.-L. Recent Advances in the Chemical Composition of Propolis. Molecules 2014, 19, 19610-19632. [CrossRef]

31. Whatmore, J.L.; Swann, E.; Barraja, P.; Newsome, J.J.; Bunderson, M.; Beall, H.D.; Tooke, J.E.; Moody, C.J. Comparative study of isoflavone, quinoxaline and oxindole families of anti-angiogenic agents. Angiogenesis 2002, 5, 45-51. [CrossRef]

32. Xuan, H.; Li, Z.; Yan, H.; Sang, Q.; Wang, K.; He, Q.; Wang, Y.; Hu, F. Antitumor Activity of Chinese Propolis in Human Breast Cancer MCF-7 and MDA-MB-231 Cells. Evid.-BasedComplement. Altern. Med. 2014, 2014, 1-11. [CrossRef]

33. Zheng, Y.; Wu, Y.; Chen, X.; Jiang, X.; Wang, K.; Hu, F. Chinese Propolis Exerts Anti-Proliferation Effects in Human Melanoma Cells by Targeting NLRP1 Inflammatory Pathway, Inducing Apoptosis, Cell Cycle Arrest, and Autophagy. Nutrients 2018, 10, 1170. [CrossRef]

34. Chen, M.-J.; Shih, S.-C.; Wang, H.-Y.; Lin, C.-C.; Liu, C.-Y.; Wang, T.-E.; Chu, C.-H.; Chen, Y.-J. Caffeic Acid Phenethyl Ester Inhibits Epithelial-Mesenchymal Transition of Human Pancreatic Cancer Cells. Evid.-BasedComplement. Altern. Med. 2013, $2013,1-7$. [CrossRef]

35. Chen, W.; Sun, Y.; Lu, C.; Chao, C. Thermal cycling as a novel thermal therapy to synergistically enhance the anticancer effect of propolis on PANC-1 cells. Int. J. Oncol. 2019, 55, 617-628. [CrossRef]

36. Awale, S.; Li, F.; Onozuka, H.; Esumi, H.; Tezuka, Y.; Kadota, S. Constituents of Brazilian red propolis and their preferential cytotoxic activity against human pancreatic PANC-1 cancer cell line in nutrient-deprived condition. Bioorg. Med. Chem. 2008, 16, 181-189. [CrossRef]

37. Duan, J.; Xiaokaiti, Y.; Fan, S.; Pan, Y.; Li, X. Direct interaction between caffeic acid phenethyl ester and human neutrophil elastase inhibits the growth and migration of PANC-1 cells. Oncol. Rep. 2017, 37, 3019-3025. [CrossRef]

38. Misir, S.; Aliyazicioglu, Y.; Demir, S.; Turan, I.; Hepokur, C. Effect of Turkish Propolis on miRNA Expression, Cell Cycle, and Apoptosis in Human Breast Cancer (MCF-7) Cells. Nutr. Cancer 2019, 72, 133-145. [CrossRef]

39. Frión-Herrera, Y.; Gabbia, D.; Scaffidi, M.; Zagni, L.; Cuesta-Rubio, O.; De De Martin, S.; Carrara, M. The Cuban Propolis Component Nemorosone Inhibits Proliferation and Metastatic Properties of Human Colorectal Cancer Cells. Int. J. Mol. Sci. 2020, 21, 1827. [CrossRef]

40. Zabaiou, N.; Fouache, A.; Trousson, A.; Buñay-Noboa, J.; Marceau, G.; Sapin, V.; Zellagui, A.; Baron, S.; Lahouel, M.; Lobaccaro, J.-M.A.; et al. Ethanolic extract of Algerian propolis decreases androgen receptor transcriptional activity in cultured LNCaP cells. J. Steroid Biochem. Mol. Biol. 2019, 189, 108-115. [CrossRef]

41. Kastan, M.B.; Bartek, J. Cell-cycle checkpoints and cancer. Nature 2004, 432, 316-323. [CrossRef]

42. Cannistrà, M.; Ruggiero, M.; Zullo, A.; Serafini, S.; Grande, R.; Nardo, B. Metastases of pancreatic adenocarcinoma: A systematic review of literature and a new functional concept. Int. J. Surg. 2015, 21, S15-S21. [CrossRef] [PubMed]

43. Maier, H.J.; Wirth, T.; Beug, H. Epithelial-Mesenchymal Transition in Pancreatic Carcinoma. Cancers 2010, 2, 2058-2083. [CrossRef] [PubMed]

44. Ji, Y.; Jia, L.; Zhang, Y.; Xing, Y.; Wu, X.; Zhao, B.; Zhang, D.; Xu, X.; Qiao, X. Antitumor activity of the plant extract morin in tongue squamous cell carcinoma cells. Oncol. Rep. 2018, 40, 3024-3032. [CrossRef]

45. Li, A.; Gu, K.; Wang, Q.; Chen, X.; Fu, X.; Wang, Y.; Wen, Y. Epigallocatechin-3-gallate affects the proliferation, apoptosis, migration and invasion of tongue squamous cell carcinoma through the hippo-TAZ signaling pathway. Int. J. Mol. Med. 2018, 42, 2615-2627. [CrossRef] [PubMed]

46. Barlak, Y.; Değer, O.; Colak, M.; Karataylı, S.C.; Bozdayı, A.M.; Yucesan, F. Effect of Turkish propolis extracts on proteome of prostate cancer cell line. Proteome Sci. 2011, 9, 74. [CrossRef] [PubMed]

47. Zhang, C.; Huang, S.; Wei, W.; Ping, S.; Shen, X.; Li, Y.; Hu, F. Development of High-Performance Liquid Chromatographic for Quality and Authenticity Control of Chinese Propolis. J. Food Sci. 2014, 79, C1315-C1322. [CrossRef]

48. Li, F.; Awale, S.; Tezuka, Y.; Esumi, H.; Kadota, S. Study on the Constituents of Mexican Propolis and Their Cytotoxic Activity against PANC-1 Human Pancreatic Cancer Cells. J. Nat. Prod. 2010, 73, 623-627. [CrossRef]

49. Elmore, S. Apoptosis: A review of programmed cell death. Toxicol. Pathol. 2007, 35, 495-516. [CrossRef]

50. Hwang, A.; Muschel, R.J. Radiation and the G2 phase of the cell cycle. Radiat. Res. 1998, 150, S52. [CrossRef]

51. Gautier, J.; Solomon, M.J.; Booher, R.N.; Bazan, J.; Kirschner, M.W. cdc25 is a specific tyrosine phosphatase that directly activates p34cdc2. Cell 1991, 67, 197-211. [CrossRef]

52. Furnari, B.; Rhind, N.; Russell, P. Cdc25 Mitotic Inducer Targeted by Chk1 DNA Damage Checkpoint Kinase. Science 1997, 277, 1495-1497. [CrossRef]

53. Abbas, T.; Dutta, A. p21 in cancer: Intricate networks and multiple activities. Nat. Rev. Cancer 2009, 9, 400-414. [CrossRef]

54. Ren, B.; Cui, M.; Yang, G.; Wang, H.; Feng, M.; You, L.; Zhao, Y. Tumor microenvironment participates in metastasis of pancreatic cancer. Mol. Cancer 2018, 17, 1-15. [CrossRef]

55. Mihaljevic, A.L.; Michalski, C.W.; Friess, H.; Kleeff, J. Molecular mechanism of pancreatic cancer-Understanding proliferation, invasion, and metastasis. Langenbeck's Arch. Surg. 2010, 395, 295-308. [CrossRef]

56. Sommariva, M.; Gagliano, N. E-Cadherin in Pancreatic Ductal Adenocarcinoma: A Multifaceted Actor during EMT. Cells 2020, 9, 1040. [CrossRef] 
57. Karayiannakis, A.J.; Syrigos, K.N.; Polychronidis, A.; Simopoulos, C. Expression patterns of alpha-, beta- and gamma-catenin in pancreatic cancer: Correlation with E-cadherin expression, pathological features and prognosis. Anticancer. Res. 2002, 21, 4127-4134.

58. Tania, M.; Khan, A.; Fu, J. Epithelial to mesenchymal transition inducing transcription factors and metastatic cancer. Tumor Biol. 2014, 35, 7335-7342. [CrossRef]

59. Wang, Y.; Shi, J.; Chai, K.; Ying, X.; Zhou, B.P. The Role of Snail in EMT and Tumorigenesis. Curr. Cancer Drug Targets 2013, 13, 963-972. [CrossRef]

60. Herranz, N.; Pasini, D.; Díaz, V.M.; Francí, C.; Gutierrez, A.; Dave, N.; Escrivà, M.; Hernandez-Muñoz, I.; Di Croce, L.; Helin, K.; et al. Polycomb Complex 2 Is Required for E-cadherin Repression by the Snail1 Transcription Factor. Mol. Cell. Biol. 2008, 28, 4772-4781. [CrossRef]

61. Peinado, H.; Ballestar, E.; Esteller, M.; Cano, A. Snail Mediates E-Cadherin Repression by the Recruitment of the Sin3A/Histone Deacetylase 1 (HDAC1)/HDAC2 Complex. Mol. Cell. Biol. 2004, 24, 306-319. [CrossRef]

62. Tseng, J.-C.; Lin, C.-Y.; Su, L.-C.; Fu, H.-H.; Yang, S.-D.; Chuu, C.-P. CAPE suppresses migration and invasion of prostate cancer cells via activation of non-canonical Wnt signaling. Oncotarget 2016, 7, 38010-38024. [CrossRef]

63. Yang, B.; Huang, J.; Xiang, T.; Yin, X.; Luo, X.; Huang, J.; Luo, F.; Li, H.; Li, H.; Ren, G. Chrysin inhibits metastatic potential of human triple-negative breast cancer cells by modulating matrix metalloproteinase-10, epithelial to mesenchymal transition, and PI3K/Akt signaling pathway. J. Appl. Toxicol. 2013, 34, 105-112. [CrossRef]

64. Chen, K.-S.; Shi, M.-D.; Chien, C.-S.; Shih, Y.-W. Pinocembrin suppresses TGF- $\beta 1$-induced epithelial-mesenchymal transition and metastasis of human Y-79 retinoblastoma cells through inactivating $\alpha \mathrm{v} \beta 3$ integrin/FAK/p38 $\alpha$ signaling pathway. Cell Biosci. 2014, 4, 41. [CrossRef]

65. Chen, D.; Li, D.; Xu, X.-B.; Qiu, S.; Luo, S.; Qiu, E.; Rong, Z.; Zhang, J.; Zheng, D. Galangin inhibits epithelial-mesenchymal transition and angiogenesis by downregulating CD44 in glioma. J. Cancer 2019, 10, 4499-4508. [CrossRef] [PubMed]

66. Kao, H.-F.; Chang-Chien, P.-W.; Chang, W.-T.; Yeh, T.-M.; Wang, J.-Y. Propolis inhibits TGF- $\beta 1$-induced epithelial-mesenchymal transition in human alveolar epithelial cells via PPAR $\gamma$ activation. Int. Immunopharmacol. 2013, 15, 565-574. [CrossRef] [PubMed]

67. Dong, J.; Feldmann, G.; Huang, J.; Wu, S.; Zhang, N.; Comerford, S.A.; Gayyed, M.F.; Anders, R.A.; Maitra, A.; Pan, D. Elucidation of a Universal Size-Control Mechanism in Drosophila and Mammals. Cell 2007, 130, 1120-1133. [CrossRef] [PubMed]

68. Lian, I.; Kim, J.; Okazawa, H.; Zhao, J.; Zhao, B.; Yu, J.; Chinnaiyan, A.; Israel, M.A.; Goldstein, L.S.; Abujarour, R.; et al. The role of YAP transcription coactivator in regulating stem cell self-renewal and differentiation. Genes Dev. 2010, 24, 1106-1118. [CrossRef]

69. Zhao, B.; Wei, X.; Li, W.; Udan, R.S.; Yang, Q.; Kim, J.; Xie, J.; Ikenoue, T.; Yu, J.; Li, L.; et al. Inactivation of YAP oncoprotein by the Hippo pathway is involved in cell contact inhibition and tissue growth control. Genes Dev. 2007, 21, 2747-2761. [CrossRef]

70. Marti, P.; Stein, C.; Blumer, T.; Abraham, Y.; Dill, M.T.; Pikiolek, M.; Orsini, V.; Jurisic, G.; Megel, P.; Makowska, Z.; et al. YAP promotes proliferation, chemoresistance, and angiogenesis in human cholangiocarcinoma through TEAD transcription factors. Hepatology 2015, 62, 1497-1510. [CrossRef]

71. Kapoor, A.; Yao, W.; Ying, H.; Hua, S.; Liewen, A.; Wang, Q.; Zhong, Y.; Wu, C.-J.; Sadanandam, A.; Hu, B.; et al. Yap1 Activation Enables Bypass of Oncogenic Kras Addiction in Pancreatic Cancer. Cell 2019, 179, 1239. [CrossRef]

72. Liang, N.; Zhang, C.; Dill, P.; Panasyuk, G.; Pion, D.; Koka, V.; Gallazzini, M.; Olson, E.N.; Lam, H.; Henske, E.P.; et al. Regulation of YAP by mTOR and autophagy reveals a therapeutic target of tuberous sclerosis complex. J. Exp. Med. 2014, 211, 2249-2263. [CrossRef]

73. Kim, W.; Khan, S.K.; Gvozdenovic-Jeremic, J.; Kim, Y.; Dahlman, J.; Kim, H.; Park, O.; Ishitani, T.; Jho, E.-H.; Gao, B.; et al. Hippo signaling interactions with Wnt/ $\beta$-catenin and Notch signaling repress liver tumorigenesis. J. Clin. Investig. 2016, 127, 137-152. [CrossRef]

74. Fernandez-L, A.; Northcott, P.A.; Dalton, J.; Fraga, C.; Ellison, D.; Angers, S.; Taylor, M.D.; Kenney, A.M. YAP1 is amplified and up-regulated in hedgehog-associated medulloblastomas and mediates Sonic hedgehog-driven neural precursor proliferation. Genes Dev. 2009, 23, 2729-2741. [CrossRef]

75. Tschaharganeh, D.F.; Chen, X.; Latzko, P.; Malz, M.; Gaida, M.M.; Felix, K.; Ladu, S.; Singer, S.; Pinna, F.; Gretz, N.; et al. Yes-Associated Protein Up-regulates Jagged-1 and Activates the NOTCH Pathway in Human Hepatocellular Carcinoma. Gastroenterology 2013, 144, 1530-1542.e12. [CrossRef]

76. Song, Y.; Fu, J.; Zhou, M.; Xiao, L.; Feng, X.; Chen, H.; Huang, W. Activated Hippo/Yes-Associated Protein Pathway Promotes Cell Proliferation and Anti-apoptosis in Endometrial Stromal Cells of Endometriosis. J. Clin. Endocrinol. Metab. 2016, 101, 1552-1561. [CrossRef]

77. Lei, Q.-Y.; Zhang, H.; Zhao, B.; Zha, Z.-Y.; Bai, F.; Pei, X.-H.; Zhao, S.; Xiong, Y.; Guan, K.-L. TAZ Promotes Cell Proliferation and Epithelial-Mesenchymal Transition and Is Inhibited by the Hippo Pathway. Mol. Cell. Biol. 2008, 28, 2426-2436. [CrossRef]

78. Shao, D.D.; Xue, W.; Krall, E.B.; Bhutkar, A.; Piccioni, F.; Wang, X.; Schinzel, A.C.; Sood, S.; Rosenbluh, J.; Kim, J.W.; et al. KRAS and YAP1 Converge to Regulate EMT and Tumor Survival. Cell 2014, 158, 171-184. [CrossRef]

79. Xia, H.; Qi, H.; Li, Y.; Pei, J.; Barton, J.; Blackstad, M.; Xu, T.; Tao, W. LATS1 tumor suppressor regulates G2/M transition and apoptosis. Oncogene 2002, 21, 1233-1241. [CrossRef] 